\title{
Miracetyma etimaruya gen. et sp. n. (COPEPODA, POECILOSTOMATOIDA, ERGASILIDAE) FROM FRESHWATER FISHES OF THE BRAZILIAN AMAZON.
}

\author{
José Celso O. MALTA ${ }^{1}$
}

\begin{abstract}
Miracetyma etimaruya gen. et sp. $\mathrm{n}$. is proposed from the gills filaments of Curimata cyprinoides (Linnaeus, 1758), Potamorhina latior (Spix, 1829) and Psectrogaster essequibensis (Gunther, 1864). The species of the new genus is characterized by having a more complex latching antenna. The claw is greatly reduced and has a groove; the third segment has one or two grooves; the first, second and third segments have one or two cuticular extensions. The legs have pectinate setae and the first endopod is greatly modified, very long, and without setae. The first segment of the first endopod is large, strong and elongate and the second segment is subcylindrical, slender and elongate. These modifications imply in a loss of swimming capacity which is linked to secure fixation on the gill filament. As a result, the leg morphology has evolved other functions.
\end{abstract}

Key words: Copepoda, Ergasilidae, new genus, Miracetyma, Amazônia.

Miracetyma etimaruya gen. et. sp. N. (Copepoda, Poecilostomatoida, Ergasilidae) dos Peixes de Água Doce da Amazônia Brasileira.

RESUMO - Miracetyma etimaruya gen. et sp. n. é proposto. Os espécimens foram coletados dos filamentos branquiais de Curimata cyprinoides (Linnaeus, 1758), Potamorhina latior (Spix, 1829) e Psectrogaster essequibensis (Gunther, 1864). A espécie deste gênero caracteriza-se por apresentar um sistema de encaixe das antenas mais complexo e eficiente. A garra é muito reduzida e possui uma ranhura; o terceiro segmento tem uma ou duas ranhuras; o primeiro, o segundo e o terceiro segmentos têm uma ou duas extenções cuticulares. As pernas apresentam setas pectinadas e o primeiro endopodito é extremamente modificado, muito longo e sem setas. O primeiro segmento do primeiro endopodito é largo, forte e alongado e o segundo segmento é subcilíndrico, fino e alongado. Estas modificações implicam na perda da capacidade natatória a qual esta ligada a uma segura fixação no filamento branquial. Como resultado da morfologia, as pernas desenvolveram outras funções.

Palavras-chave: Copepoda, Ergasilidae, gênero novo, Miracetyma, Amazônia.

\section{INTRODUCTION}

The South American species of parasitic copepods of freshwater fishes are included in 4 families and 13 genera. Ergasilidae with 6 genera: Ergasilus Nordmann, 1832; Acusicola Cressey, 1970; Brasergasilus Thatcher \& Boeger,
1983; Amplexibranchius Thatcher \& Paredes, 1985; Rhinergasilus Boeger \& Thatcher, 1988 and Prehendorastrus Boeger \& Thatcher, 1990. Vaigamidae with 4 genera: Vaigamus Thatcher \& Robertson, 1984; Gamidactylus Thatcher \& Boeger, 1984; Gamispinus Thatcher \& Boeger, 1984 and

I Instituto Nacional de Pesquisas da Amazônia, Coordenação de Pesquisas em Biologia Aquática, Caixa Postal 478, 69011-970 - Manaus, Amazonas, Brasil. 
Gamispatulus Thatcher \& Boeger, 1984. Lemaeidae with 2 genera Taurocheros Brian, 1924 and Perulernaea Thatcher \& Paredes, 1985. Amazonicopeidae with 1 genus Amazonicopeus Thatcher, 1986.

There are 6 attachment sites on fishes used by copepods, namely: gills filaments, gills rakers, nasal fossae, skin, fins and muscles. The present paper includes the description of a new species that attaches to gills filaments and proposes a new genus to include this form.

\section{MATERIAL AND METHODS}

The fishes were captured during 4 expeditions in Rondônia state. The first was from November 7 to December 1 1983, during high water, in the Jiparaná River (Machado) and Urupá, near Jiparaná; Jamari River, near Ariquemes; Guaporé River, near Costa Marques and Pacaás Novos River, near GuajaráMirim. The second expedition was from 15 April to 10 May 1984, during high water. The same River localities were collected except Guaporé River near Surpresa. The third collecting trip was from November 23 to December 91984 , during high water and was to the Guaporé River near Pimenteiras and the Jamari River near the site of the Samuel reservoir. The fourth trip was from September 15 to October 4 1985, during low water, to the Guapore River and Mamoré River near Surpresa, Pacaás Novos River near Guajará-Mirim and Jiparaná River (Machado) near Jiparaná (Fig. 1).

Samples of fishes were obtained by gill-netting with length range of 15 to $40 \mathrm{~m}$, and height ranges of 1 to $3 \mathrm{~m}$ and mesh ranges of 30 and $140 \mathrm{~mm}$. Each station was sampled during 24 hours and a sample was taken each 6 hours. Fishes were identified and the fork length and weight were recorded. Gills and visceras were removed and were fixed in formalin $10 \%$.

The copepods were removed from the gills of fish using fine needles and a dissecting microscope. Ergasiloids were transferred to formalin at $5 \%$. Specimens were stained with a mixture of eosin and orange $\mathrm{G}$ in $95 \%$ ethanol. Permanent preparations were made by dehydrating in phenol, clearing in methyl salicylate, and mounting in balsam. Drawings were made with the aid of a camera lucida. Measurements were obtained with a measuring ocular and are given in micrometers. The range is given followed by the average in parentheses.

Types were deposited in the collections of the Instituto Nacional de Pesquisas da Amazônia, (INPA-CR), Manaus and Museu de Zoologia da Universidade de São Paulo, (MZUSP), São Paulo.

\section{Miracetyma gen. nov.}

Generic diagnosis: Ergasilidae, Acusicolinae, Female: cephalothorax inflated, or not. Abdomen 3-segmented. Antennule 5-segmented. Antenna 3-segmented, claw greatly reduced and with a groove; third segment with one or two grooves; segment two long; first, second and third segments with one or two cuticular extensions. 


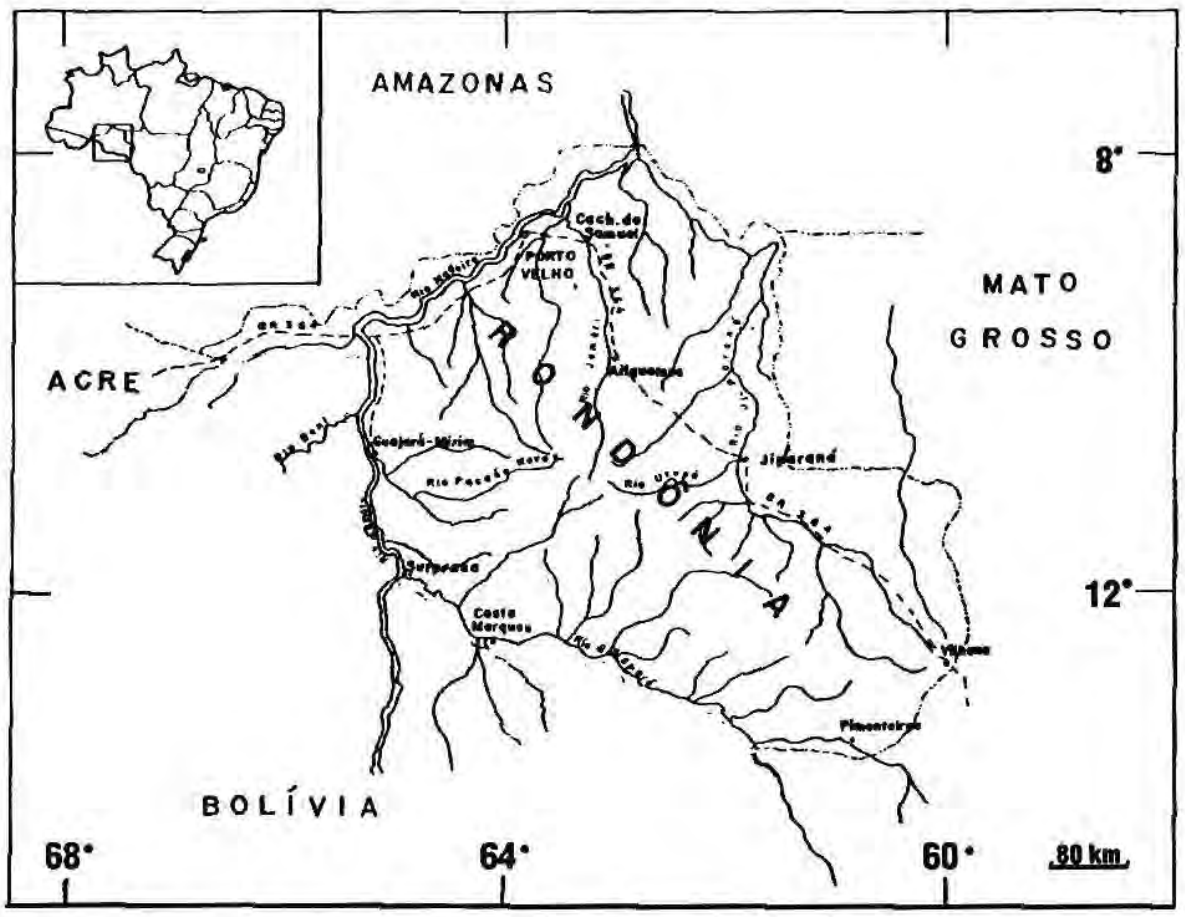

Figure 1. Map of Rondônia state indicating the collecting areas on the rivers: Guaporé; Mamoré; Pacaás Novos; Jiparaná; Jamari and Urupá.

Maxillipeds absent. Legs 1 - 4 biramous; all setae pectinate; first endopod and fourth exopod 2-segmented, the others 3-segmented; first endopod extremely modified, very long, and without setae. First segment of first endopod large, strong and elongate; second segment subcylindrical, slender and elongate. Leg V represented by one or two simple setae. Leg VI absent. Male: unknown, but presumably free-living. Female parasitic on gills filaments of fishes.

Etymology: The generic name comes from Tupi-Guarani (amerind name): "mira", wood and Tupi "cetyma", leg; the first endopod resembles a wooden leg.
Type species: Miracetyma etimaruya sp. $\mathbf{n}$.

\section{Miracetyma etimaruya sp, $\mathbf{n}$.}

(Figs. 2 - 12)

Material examined:

Holotype: female (INPA-CR $600)$, from the gills of Curimata cyprinoides collected in Jamari River, Ariquemes, 8-vi-1984, on slide, Paratypes: 8 females (INPA-CR 601a - h) and 2 females (MZUSP 10440a b) all on slide; 13 females (INPA-CR 602) and 3 females (MZUSP 10441) all in formalin 5\%; from the gills of 5 specimens of Curimata cyprinoides (17 examined), from type locality and 


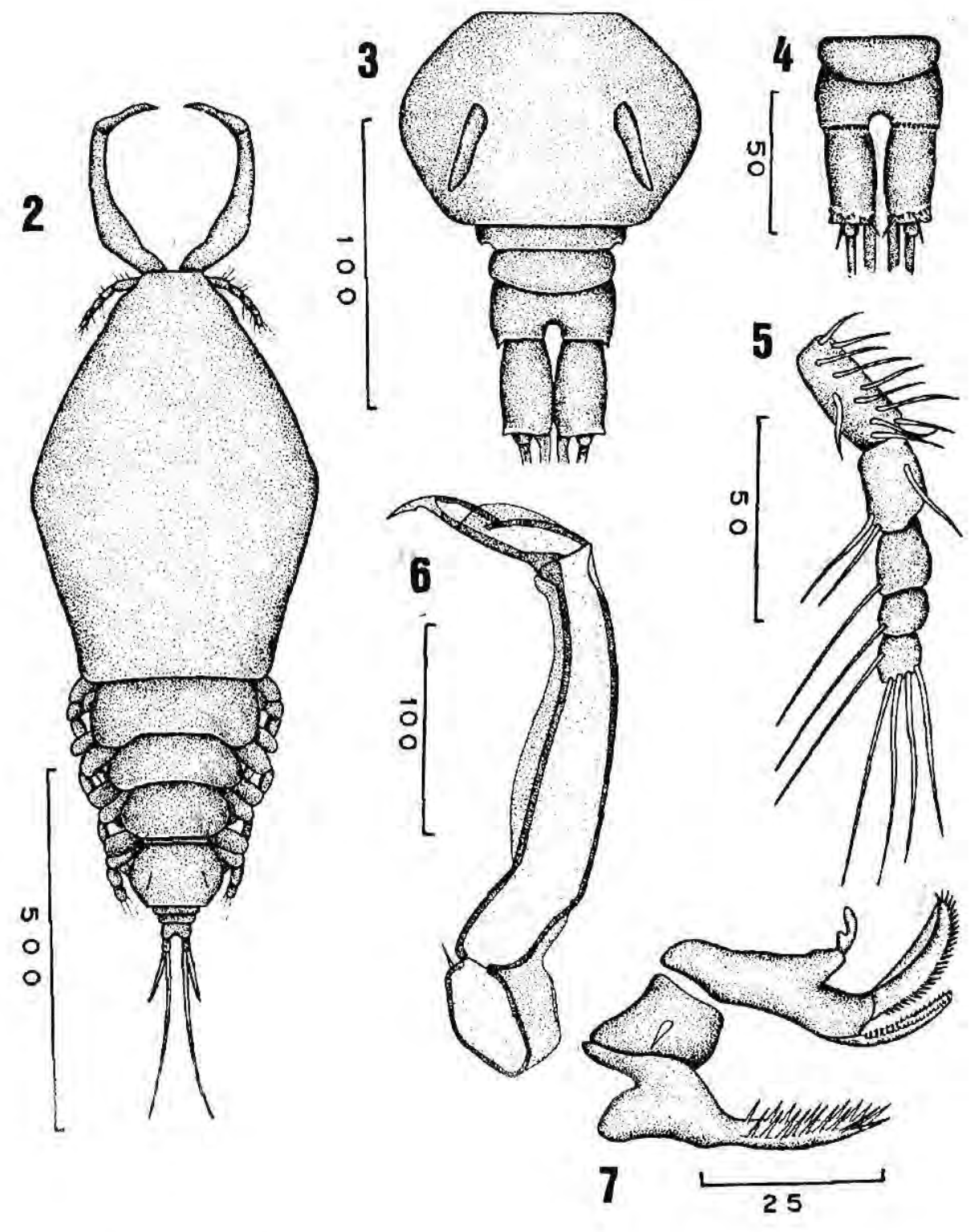

Figures Miracetyma etimaruya gen. et sp. nov. (female). 2 - dorsal view, 3 - genital double somite, abdomen and caudal rami. 4 - caudal rami (ventral view). 5 - antennule. 6 - antenna. 7 - mouthparts. 
Jiparaná River, Jiparaná; 4 specimens of Potamorhina latior (10 examined), from Guaporé and Mamoré River, Surpresa, 24-ix-1985; 2 specimens of Psectrogaster essequibensis (4 examined) from Pacaás Novos River, Guajará-Mirim, 27-ix-1985. All collected by J. C. O. Malta.

Description: (based on 20 specimens and 10 measured Tab. 1 and 2). Cephalothorax (Fig. 2) hexagonal, trunk little developed, median region wide; 5.5 times wider than anterior region; head totally fused with first two thoracic somites.

Thorax (Fig. 2) of four free somites.

Abdomen (Figs. 2, 3 and 4) with the genital double somite hexagonal (Figs. 2 and 3) and three somites, last somite with one row of spinules on the posterior ventral margin and one lateral spine. Caudal rami (Figs. 2, 3 and 4), with one long and one short seta, one row of spinules on the posterior ven-

Table 1. Measurements $(\mu \mathrm{m})$ of 10 adult females of Miracetyma etimaruya gen. et sp. nov.

\begin{tabular}{|c|c|c|c|c|c|}
\hline \multirow[b]{2}{*}{$\begin{array}{l}\text { Body } \\
\text { Cephalothorax }\end{array}$} & \multicolumn{2}{|r|}{ Length } & \multicolumn{3}{|c|}{ Width } \\
\hline & $\begin{array}{l}802 \\
454\end{array}$ & $\begin{array}{l}-936(875) \\
-596(538)\end{array}$ & $\begin{array}{l}286 \\
286\end{array}$ & $\begin{array}{l}-357 \\
-357\end{array}$ & $\begin{array}{l}(303) \\
(303)\end{array}$ \\
\hline $\begin{array}{l}\text { Free thoracic somites } \\
\text { III } \\
\text { IV } \\
\text { V } \\
\text { VI }\end{array}$ & $\begin{array}{l}60 \\
52 \\
42 \\
10\end{array}$ & $\begin{array}{ll}-75 & (68) \\
-72 & (63) \\
-55 & (47) \\
-22 & (18)\end{array}$ & $\begin{array}{r}130 \\
112 \\
85 \\
55\end{array}$ & $\begin{array}{l}-200 \\
-150 \\
-105 \\
-67\end{array}$ & $\begin{array}{r}(178) \\
(138) \\
(98) \\
(58)\end{array}$ \\
\hline $\begin{array}{l}\text { Abdominal somites } \\
\text { Genital double somite } \\
\text { II } \\
\text { III }\end{array}$ & $\begin{array}{l}52 \\
10 \\
10 \\
20\end{array}$ & $\begin{array}{l}-75(65) \\
=15(12) \\
=12(11) \\
-25(23)\end{array}$ & $\begin{array}{l}80 \\
45 \\
42 \\
40\end{array}$ & $\begin{array}{r}-100 \\
-\quad 57 \\
-57 \\
-60\end{array}$ & $\begin{array}{l}(91) \\
(53) \\
(47) \\
(47)\end{array}$ \\
\hline Caudal rami & 30 & $-50 \quad(33)$ & 35 & -50 & $(40)$ \\
\hline Caudal Setae & & - & & - & \\
\hline Egg sac & 318 & $-535(383)$ & 60 & $\cdot 97$ & (75) \\
\hline
\end{tabular}

tral margin and two terminal reduced setae.

Antennule (Fig. 5 and Tab. 2) 5 segmented, setae simple, setal formula: $11-3-1-1-5$. Antenna (Fig. 6 and table II) 3-segmented, first segment short, narrow, with a distal spinule and a cuticular extension on the external margin. This extension is almost of same width as the segment extends anteriorly one-fifth of external margin of next segment. Second segment very long and with a cuticular extension on three-fourths of internal margin distally; third segment with a deep groove mid-way on its length and a cuticular extension on the external margin; claw, small, with a groove on internal margin. Ratio of segmental lengths 2.3 : $7.2: 2.2: 1.0$.

Mouthparts (Fig. 7): mandible, long with one distal falciform blade, long denticulated along posterior margin; on posterior margin of appendage long narrow palp with two rows of denticles on anterior margins; maxillule very small, with narrow basal part and tapering, medial region with one seta; maxilla with a robust base and tapering, falciform distal process with two rows of spiniform setae on anterior margin.

Legs (Figs. 8, 9, 10, 11 and Tab. 3). Setae on legs 1 - 4 pectinate. Leg I (Fig. 8) endopod 2-segmented and exopod 3-segmented. Endopod modified, very long, first segment strong, long, sub-rectangular with spines on external distal region, 1.2 times longer and 2.0 times wider that exopod; second segment long, slender 1.5 times 
Table 2. Antennal measurements $(\mu \mathrm{m})$ of 10 adult females of Miracetyma etimaruya gen. et sp. nov.

\begin{tabular}{lrrrrr}
\hline & \multicolumn{2}{c}{ Length } & \multicolumn{2}{c}{ Width } \\
Antennule & $100-117$ & $(109)$ & $17-30$ & (21) \\
Antenna & & & & & \\
Segment 1 & $57-95$ & $(72)$ & $27-55$ & $(41)$ \\
2 & $187-230$ & $(225)$ & $30-47$ & $(38)$ \\
3 & $76=87$ & $(81)$ & $17-25$ & $(19)$ \\
claw & $31-36$ & $(31)$ & $12-15$ & $(14)$ \\
\hline
\end{tabular}

longer and 2.4 times narrower than exopod. Exopod, all segments with spinules on external margins. First exopodal segment with a postero-lateral row of spinules; second segment with one seta medially; terminal segment with five setae and one spine postero-laterally. Leg II and III (Fig. 9) closely similar, all rami 3-segmented. All endopodal segments with spinules on external margins. First endopodal segment with one seta medially; second segment with two setae laterally; terminal segment with four setae laterally, one terminal spine and distal margin forming a straight line. First exopodal segment strong and wide, second segment with one lateral seta; terminal segment with six terminal setae. Leg IV (Fig. 10) endopod 3segmented and exopod 2-segmented. All endopodal segments with spinules on external margins. First endopodal

Table 3. Relationship of spines (Roman) to setae (Arabic) on the legs of Miracetyma etimaruya gen. et sp. nov.

\begin{tabular}{llll}
\hline & & \multicolumn{1}{c}{ Exopod } & \multicolumn{1}{c}{ Endopod } \\
Leg I & $0-0,0-1,1-5$ & $0-0,0-0$ \\
Leg II & $0-0,0-1,0-6$ & $0-1,0-2,1-4$ \\
Leg III & $0-0,0-1,0-6$ & $0-1,0-2,1-4$ \\
Leg & $N$ & $0-0,0-5$ & $0-1,0-2, I I-2$ \\
\hline
\end{tabular}

segment with one medial seta; second segment with two medial setae, terminal segment with two setae and two spines. First exopodal segment without ornaments; second segment with five lateral setae. Leg V (Fig. 11) vestigial, consisting of two simple setae arising from small papilla.

Egg sac (Fig. 12) with two rows, 13 - 25 eggs.

\section{Male: Unkonwn.}

Etymology: The specific name comes from Tupi-Guarani (amerind name): "etima" leg; "ru" with and "yu" spine; legs with spines (in reference to the presence of spines on all the legs).

\section{DISCUSSION}

JOHNSON \& ROGERS (1972) and KABATA (1979) rejected the genus Acusicola Cressey, 1970. THATCHER (1984) retained the genus Acusicola, proposed the subfamily Acusicolinae (Ergasilidae) and included three more species: A. lycengraulidis Thatcher \& Boeger, 1983; A. pellonidis Thatcher \& Boeger, 1983, and $A$. tucunarense Thatcher, 1984. Thatcher \& Paredes, 1985, included the genus Amplexibranchius in this subfamily.

Acusicolinae is defined as those ergasilids in which the females have 4 pairs of swimming legs ( 5 th pair vestigial), antennule 5-segmented, antenna . 3-segmented with a groove in the third segment for the reception of the opposite claw when the antennae are latched. Acusicolinae differ from other ergasilids in having evolved antennae which encircle the gill filament and 

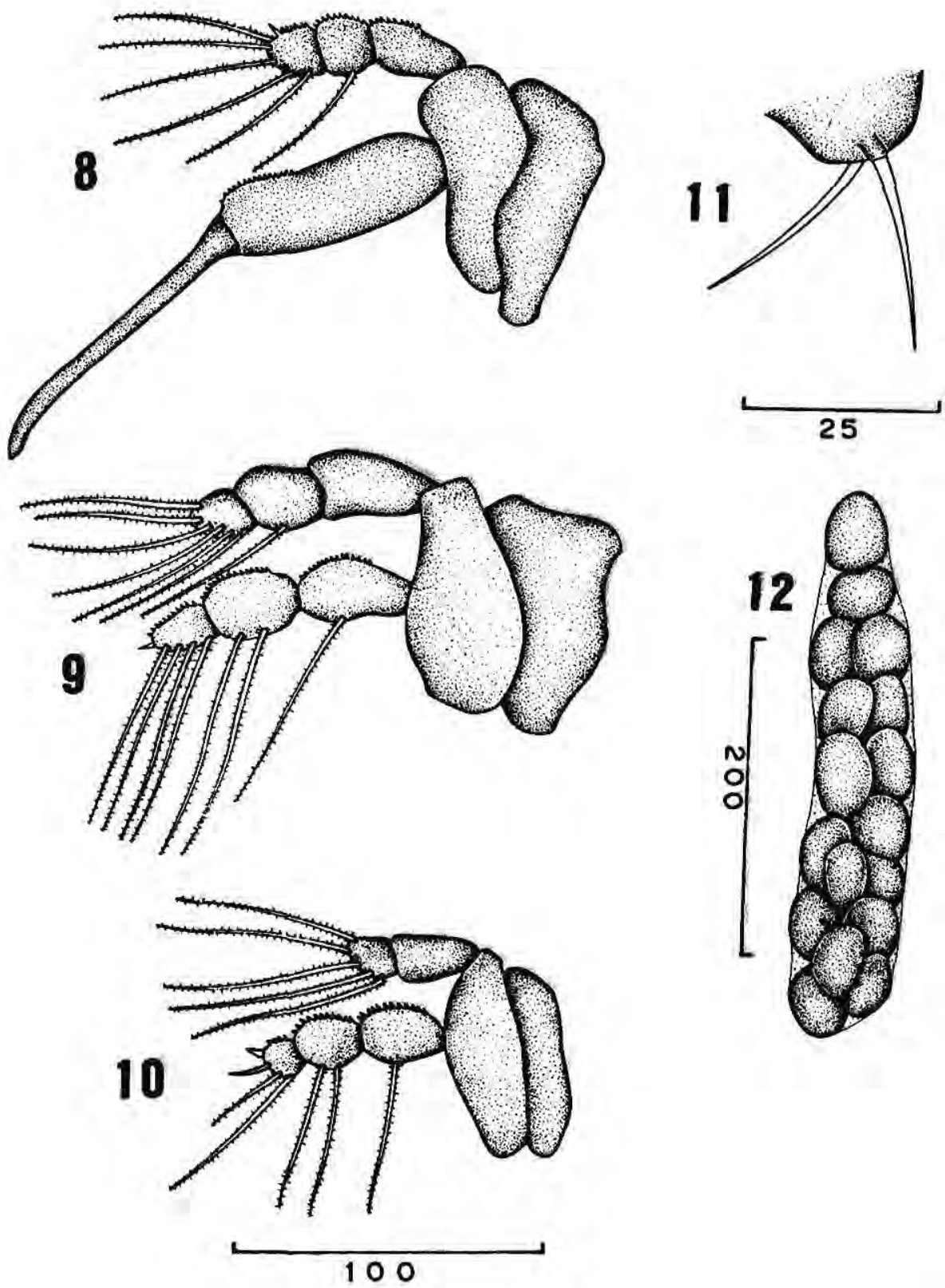

Figures Miracetyma etimaruya gen. et sp. nov. (female). 8 - leg I. 9 - leg II (= leg III). 10 - leg IV. 11 - leg V. 12 - egg sac. 
latch in place. The latching device is composed of the grooved third segment and the claw. When the antennae are latched, each claw fits into a groove on the third segment of the opposite antenna (THATCHER \& PAREDES, 1985).

Acusicola pellonidis is an example of the simplest latch and in this type, the point of the claws are completely exposed, in A. cunula Cressey, 1970 and $A$. lycengraulis there is a small cuticular flap from the distal end of the second segment which partially covers the tip of the claw. In Amplexibranchius bryconis there is a more complex antennal latch, with a sleeve-like extension of the second segment which covers most of the third so that when the antennae are latched, the claws are completely covered (THATCHER \& PAREDES, op. cit.).

Miracetyma gen. nov., is included in the subfamily Acusicolinae, because the antennae have the same device, but the antennal latch is more complex. Sleeve-like extensions cover the external margin of first and the anterior fifth of the second segment, three-fourth of internal margin of second segment and external margin of third segment in $M$. etimaruya. $M$. etimaruya has one groove on the external margin of the third antennal segment and a groove on the posterior margin of the claw. When the antennae are latched, each groove of the claw fits into a groove on the third segment of the opposite antennae. In this genus the claws are smaller than in
Amplexibranchius and may serve as a sort of safety catch.

THATCHER \& PAREDES, $(o p$. cit) suggested that the legs of most ergasiloids are not modified for parasitism but are tied to a swimming function. Some species of Ergasilus detach readily from the hosts gills and swim actively. Specimens of Ergasilus and Vaigamidae are found in plankton samples. Ga.nispinus (Vaigamidae) has also been observed to swim rapidly when dissected from the nasal mucous. It is possible that ergasiloids use this swimming ability to move from one gill filament to another, or to change hosts. After the latching antennae of Acusicolinae evolved, the necessity of moving was eliminated and the legs were freed from their swimming function. As result, the legs have evolved other functions related to the parasitic way of life and have modified their morphology accordingly.

In Miracetyma gen. nov. the hypothesis above is corroborated. The antennae are seen to have a more efficient latching device, the legs are free from their swimming function. As a result, the first endopod has became greatly modified. The first segment is stout and long and the second is slender and elongated. These animals may use these structures like long tweezers to conduct food to the mouth. It would appear that this may be a more efficient feeding strategy than that used by other poecilosmatoids. Leg morphology is used to define a genus, for the second time. 


\section{ACKNOWLEDGEMENTS}

I would like to thank Dr. V. E. Thatcher and Dra. A. Varella for the critical review of the manuscript.

\section{References}

JOHNSON, S. K.; ROGERS, W. A. 1972. Ergasilus clupeidarum sp. nov. (Copepoda: Cyclopoida) from clupeid fishes of the Southeastern U. S. with a synopsis of the North American Ergasilus species with a two-jointed first endopod. J. Parasit., 58:385-392.
KABATA, Z, 1979. Parasitic Copepoda of British Fishes. London: Ray Society, $667 \mathrm{p}$.

THATCHER, V. E. 1984. The parasitic crustaceans of fishes from the Brazilian Amazon. 7. Acusicola tucunarense, $\mathrm{n}$. sp.(Copepoda: Ciclopoidea) from Cichla ocellaris, with emendation of the genus and the proposal of Acusicolinae subfam. nov. Rev. Bras. Biol., 44 (2):181-189.

THATCHER, V. E.; PAREDES, V. 1985. A parasitic copepod, Amplexibranchius bryconis gen. et sp. nov. (Ergasilidae: Acusicolinae) from an Amazonian fish and remarks on the importance of leg morphology in this subfamily. Amazoniana, 9 (2): 205-214.

Aceito em 24/03/93 